\title{
Simulation-based neonatal resuscitation training of medical students: is Peyton's 4-stage approach more effective than traditional 2-stage technique?
}

\author{
Erol Tutdibi ${ }^{*}$, Ludwig Gortner ${ }^{1}$, Thomas Volk $^{2}$, Erik Reus ${ }^{2}$ \\ From 50th Workshop for Pediatric Research \\ Gottingen, Germany. 20-21 March 2014
}

Resuscitation of newborns is a critical procedure and requires refined skills. The contents of resuscitation guidelines and their implementation should be crucial in education of medical students. The traditional 2-stage ("see one, do one") instruction is theory-loaded and does not provide sufficient hands-on training needed to give trainees the necessary practical experience or confidence in clinical skills. We aimed to evaluate whether simulation-based skill training by Peyton's 4-step approach can improve the performance of medical students in neonatal resuscitation compared to traditional front-side 2 -step teaching. In a prospective trial design, 49 fourth-year medical students were randomized in traditional and 4-stage groups. According to the "see one, do one" principle in the traditional group the teacher at first explained the ERC-algorithm and demonstrated the neonatal resuscitation procedure before the practitioners could train on manikins. In the "Peyton" group students were divided in small-groups with 4 trainees each and received 4-step approach training. Three days after the initial neonatal resuscitation training all students passed a standardized simulation-based scenario with newborn manikins to assess the effect of both teaching methods by an objective structured clinical examination (OSCE) and binary checklist. We modified the OSCE with a practical (pOSCE, maximal score 118) and a theoretical part (tOSCE, maximal score 74). Students in 4-stage group scored significantly higher than traditional trained participants: $113 \pm 5$ vs. $68 \pm 23$ (pOSCE) and $66 \pm 5$ vs. 40 \pm 23 (tOSCE), all $\mathrm{p}<0.001$. In conclusion, our study

'Department of Pediatrics and Neonatology, Intensive Care Medicine and

Pain Therapy, University of Saarland, 66421 Homburg/Saar, Germany

Full list of author information is available at the end of the article demonstrates that simulation-based training by Peyton's 4-stage approach is effective to increase the performance of medical students in neonatal resuscitation.

\section{Authors' details}

'Department of Pediatrics and Neonatology, Intensive Care Medicine and Pain Therapy, University of Saarland, 66421 Homburg/Saar, Germany.

${ }^{2}$ Department of Anaesthesiology, Intensive Care Medicine and Pain Therapy, University of Saarland, 66421 Homburg/Saar, Germany.

Published: 11 September 2014

\section{doi:10.1186/2194-7791-1-S1-A4}

Cite this article as: Tutdibi et al: Simulation-based neonatal resuscitation training of medical students: is Peyton's 4-stage approach more effective than traditional 2-stage technique? Molecular and Cellular Pediatrics 2014 1(Suppl 1):A4.

Submit your manuscript to a SpringerOpen ${ }^{\circ}$ journal and benefit from:

- Convenient online submission

- Rigorous peer review

- Immediate publication on acceptance

- Open access: articles freely available online

- High visibility within the field

- Retaining the copyright to your article

Submit your next manuscript at $>$ springeropen.com
(C) 2014 Tutdibi et al; licensee Springer This is an Open Access article distributed under the terms of the Creative Commons Attribution License (http://creativecommons.org/licenses/by/2.0), which permits unrestricted use, distribution, and reproduction in any medium, provided the original work is properly cited. 